\title{
The banking-industry relationship in Italy: large national banks and small local banks compared (1913-1936)
}

Article

Accepted Version

Rinaldi, A. and Spadavecchia, A. (2021) The banking-industry relationship in Italy: large national banks and small local banks compared (1913-1936). Business History, 63 (6). pp. 9881006. ISSN 1743-7938 doi:

https://doi.org/10.1080/00076791.2019.1598975 Available at https://centaur.reading.ac.uk/83203/

It is advisable to refer to the publisher's version if you intend to cite from the work. See Guidance on citing.

To link to this article DOI: http://dx.doi.org/10.1080/00076791.2019.1598975

Publisher: Taylor \& Francis

All outputs in CentAUR are protected by Intellectual Property Rights law, including copyright law. Copyright and IPR is retained by the creators or other copyright holders. Terms and conditions for use of this material are defined in the End User Agreement.

www.reading.ac.uk/centaur 
Central Archive at the University of Reading

Reading's research outputs online 


\title{
The banking-industry relationship in Italy: Large national banks and small local banks compared (1913-1936)
}

\author{
Alberto Rinaldi ${ }^{1}$ \\ (Università di Modena e Reggio Emilia) \\ alberto.rinaldi@unimore.it \\ Anna Spadavecchia \\ (Henley Business School, University of Reading) \\ a.spadavecchia@henley.ac.uk
}

\begin{abstract}
:
Using a large dataset of Italian joint-stock companies, this article analyses the networks of corporate interlocks of the major universal banks and twenty most 'central' local banks in a critical period of Italian industrialisation. The networks of the two types of banks were largely independent, with universal banks being affiliated principally to larger concerns in electricity, transport and storage, and financials; and local banks to riskier, younger and smaller firms in light manufacturing. The article then explores whether the bank-industry relationship in Italy reflected the hegemony of banks and followed a bank-control model. Our analysis does not support that view. It rather indicates that interlocking directorates were driven principally by a convergence of interests between banks (monitoring customers) and industrial firms (interested in tapping capital and credit flows), with the latter exerting a slightly higher influence over the former. This significantly differentiates Italy from Germany and the USA, where banks had a more dominant position in the corporate system.
\end{abstract}

Key words: universal banking; local banks; interlocking directorates; Italy; networks

\footnotetext{
${ }^{1}$ Corresponding author: alberto.rinaldi@unimore.it
} 


\section{Introduction}

Italy occupies an important place in the literature on the bank-industry relationship. In his path-breaking contribution, Gerschenkron (1962) argued that banks played a pivotal role in industrialisation for 'moderately backward' countries where they acted as a substitute for financial markets in their bid to catch up with the early industrialiser, Great Britain. As a result, Italy became a well-known case of a bank-oriented financial system, a group often associated with France, Germany, and Japan (Lescure, 2008; Rajan \& Zingales, 2003).

Gerschenkron singled out the main universal banks, founded in the 1890s with German capital, as the major driver of Italy's 'big spurt' in the years prior to World War I. These banks functioned as a 'substitution factor' that prompted Italy's economic growth by providing financial support and managerial advice to the major industrial companies, especially in modern capital-intensive sectors such as steel, heavy engineering, electricity, and shipping. According to Gerschenkron, universal banks exerted considerable influence and control over industrial firms through three major channels: capital participation, sharing of board members, and monitoring of day-to-day financial affairs. However, the role of universal banks has been reconsidered by a more recent 'revisionist' historiography. In particular, Fohlin $(1998,1999)$ found evidence that these banks had a limited impact on capital mobilisation, industrial investment and economic growth. Furthermore, she highlighted that universal banks tended to establish their networks with large well-established companies instead of trying to create connections with promising, but risky, small firms, which needed venture capital.

Despite the relevance of the relationship between banks and industry, only a few studies have analysed interlocking directorates between Italian banks and industrial companies in the pre-World War II period. Cohen (1967), and Fohlin (1999) found that universal banks were at 
the centre of an entangled network with large firms in modern capital-intensive sectors such as electric power, chemicals, iron and steel, and shipyards. However, Vasta \& Baccini (1997) argued that the Italian corporate network was not characterised by such a strong centrality of banks. The location of banks at the centre of the network could be detected in 1911 and even more in 1927, but this was no longer the case in 1936, after the collapse of the universal banks. Moreover, Vasta et al. (2017) argued that Italian capitalism is structured to a remarkable extent on a sizeable and stable system of corporate interlocks that existed in parallel to that centred on the universal banks. They also showed that the influence, at least in Lombardy and some other areas of the North, was exerted by local banks that in turn developed a dense web of ties with industrial firms in both capital-intensive and labourintensive industries.

None of these previous studies analysed the directionality of interlocks, however, and whether these were an instrument for banks to exert an influence on industry or vice versa. To date, two alternative views have been proposed in the literature. The 'bank control' model places banks at the top of the decision-making hierarchy within a group of companies, using this power in their own interest; control of credit flows and, more rarely, part of the firm's equity enables banks to determine industrial firms' strategies. Or, in a less radical view, bank control can be interpreted as ensuring efficient monitoring of resources provided by banks to industrial concerns. The use of interlocking directorates plays a central role in this respect. In fact, the presence of bank fiduciaries on company boards serves as a major instrument to enforce this control and indicates the pre-eminence of banks over industrial firms (Kotz, 1978).

Conversely, 'resource dependence' models argue that restrictions on resources, information, or markets stimulate firms to create business groups, whose presence can be 
detected through the existence of interlocking directorates. The hypothesis is that companies use the sharing of board members as means to co-opt or absorb, partially or completely, other organisations with which they are interdependent (Aldrich \& Pfeffer, 1976; Pfeffer \& Salancik, 1978; Pfeffer, 1988). In the case of the bank-industry relationship, interlocking directorates are not an instrument for banks to exert control over industry, but are driven by a convergence of interests between banks (monitoring customers) and industrial firms (participating in decisions about capital and credit allocation). Moreover, for an individual firm, corporate interlocks provide business scan - i.e., access to information about other sectors of the economy - and, because of their unique role in the economy, banks are privileged in the types of information to which they have access (Useem, 1984). Thus, banks have been uniquely successful in recruiting outside directors from heavily interlocked firms because bank board membership provides information about capital flows as well as information about many other sectors (Mintz \& Schwartz, 1985).

This article adds to previous literature by exploring these two hypotheses in context of the bank-industry relationship in Italy during the first third of the twentieth century when universal banking was in place there. The core issue of the directionality of the bankingindustry relationship is investigated for large universal banks and small local banks in a comparative perspective in three benchmark years: 1913, 1927, and 1936. The comparative analysis is justified by the fact that Italy had a segmented banking system, i.e. very few large banks and a multitude of local banks with mostly local clienteles (Carnevali, 2005). Thus, for each of these years, we selected the major German-style universal banks - defined as the largest universal banks that had branch networks which covered most of the peninsula - and the twenty most 'central' local banks in the whole Italian corporate network. 


\section{The Dataset}

The source we used for this work is Imita.db, a large database of Italian joint-stock companies. ${ }^{1}$ We selected the largest nation-wide German-style universal banks - Banca Commerciale Italiana (henceforth Comit), Credito Italiano (henceforth Credit), Banco di Roma (henceforth BdR), Banca Nazionale di Credito (henceforth BNC), and Società Bancaria Italiana (henceforth SBI) ${ }^{2}$ - and the twenty most 'central' local banks by nBetweenness centrality. ${ }^{3}$ As for the directors, we only used data for members of a board of directors, excluding members of Collegi sindacali. ${ }^{4}$

Network analysis presumes that central actors have better access to information, better opportunities to spread information, and some "power" to coordinate the whole network. Degree centrality is the most straightforward measure of actor centrality and is based on the total number of direct ties between a given company and all others. An alternative is closeness centrality, based on the distance between nodes. Central actors are defined as having 'minimum steps' between themselves and other actors. Thus, the closeness centrality of a node is calculated as the reciprocal of the sum of the length of the shortest paths between the node and all other nodes. Different from degree centrality, closeness centrality considers also indirect ties between nodes. However, the nodes to which an actor relates can still be at the periphery of the network. This shortcoming is overcome by nBetweenness centrality. This measure is based on the idea that a firm is more central if it is more important as an intermediary in the communication network: it calculates the number of shortest paths between any pairs of actors in the network that pass through any given actor (De Nooy, Mrvar \& Batagelj, 2011). Thus, we resort to this latter indicator to select the top twenty local banks whose networks are analysed in this paper. The underlying assumption is that the top twenty 
by nBetweenness had better access to information, better opportunities to spread information, and were in a better position to coordinate the whole network than the remaining local banks.

By 1913, three of the four major universal banks were well placed amongst the most central firms in the Italian corporate network - SBI and Comit in the top five and Credit thirteenth - and their degrees were sizeable as well, with only BdR lagging behind. ${ }^{5}$ By that time several local banks, despite their smaller size, had also developed their web of interlocks and one of them, Banca Bergamasca di Depositi e Conti Correnti had an even higher nBetweenness and the same degree as Credit. Overall, we found six local banks in the highest decile of nBetweenness.

In subsequent years, the major universal banks further strengthened their central position in the ranking. The year 1927 represents the apex of the role of these banks: Comit ranked $1^{\text {st }}$ and the remaining three amongst the top six. The top twenty local banks, despite the high churning in the group, improved their position in the ranking of most central firms as now all of them were in the highest decile of nBetweenness; their average degree also rose to 52.4 and was three times as high as in 1913 (detailed statistical information is included in the on-line Appendix).

When the Great Depression struck, the three major universal banks and their industrial clients were bailed out by the newly created big state-owned holding IRI (Istituto per la Ricostruzione Industriale or Institute for Industrial Recovery). In 1936, a new Banking Law imposed the end of universal banking in Italy. Banks were allowed to practice only short-term credit, while their share participation in non-financial firms was strictly limited. At the same time, industrial credit was entrusted to newly created specialized institutes, many of them state-owned (La Francesca, 2004). 
These changes had profound effects on the structure of the Italian corporate network and in 1936 the three major universal banks lost their pre-eminent position. Conversely, local banks' networks seem to have better withstood the Great Depression. In 1936 all the top twenty local banks were once again in the highest decile of nBetweenness and above all, their average nBetweenness dropped much less (25 percent) than that of the major universal banks (56 percent). Similarly, the number of interlocks also diminished proportionally less for the top twenty local banks ( 35 percent) than for the major universal banks (55 percent).

\section{A comparison of the major universal banks' and twenty local banks' networks}

In all benchmark years most of the top twenty local banks (between 60 and 75 percent overall) were headquartered in Lombardy and in the other regions of the North-West that is in the area with the longest history of industrialisation. The North-East and Centre accounted for between 25 and 35 percent of the top twenty. Networks of Southern local banks were instead nearly absent, with just one occurrence in 1913 and 1927 and none in 1936.

Figure 1. Italian macro regions 


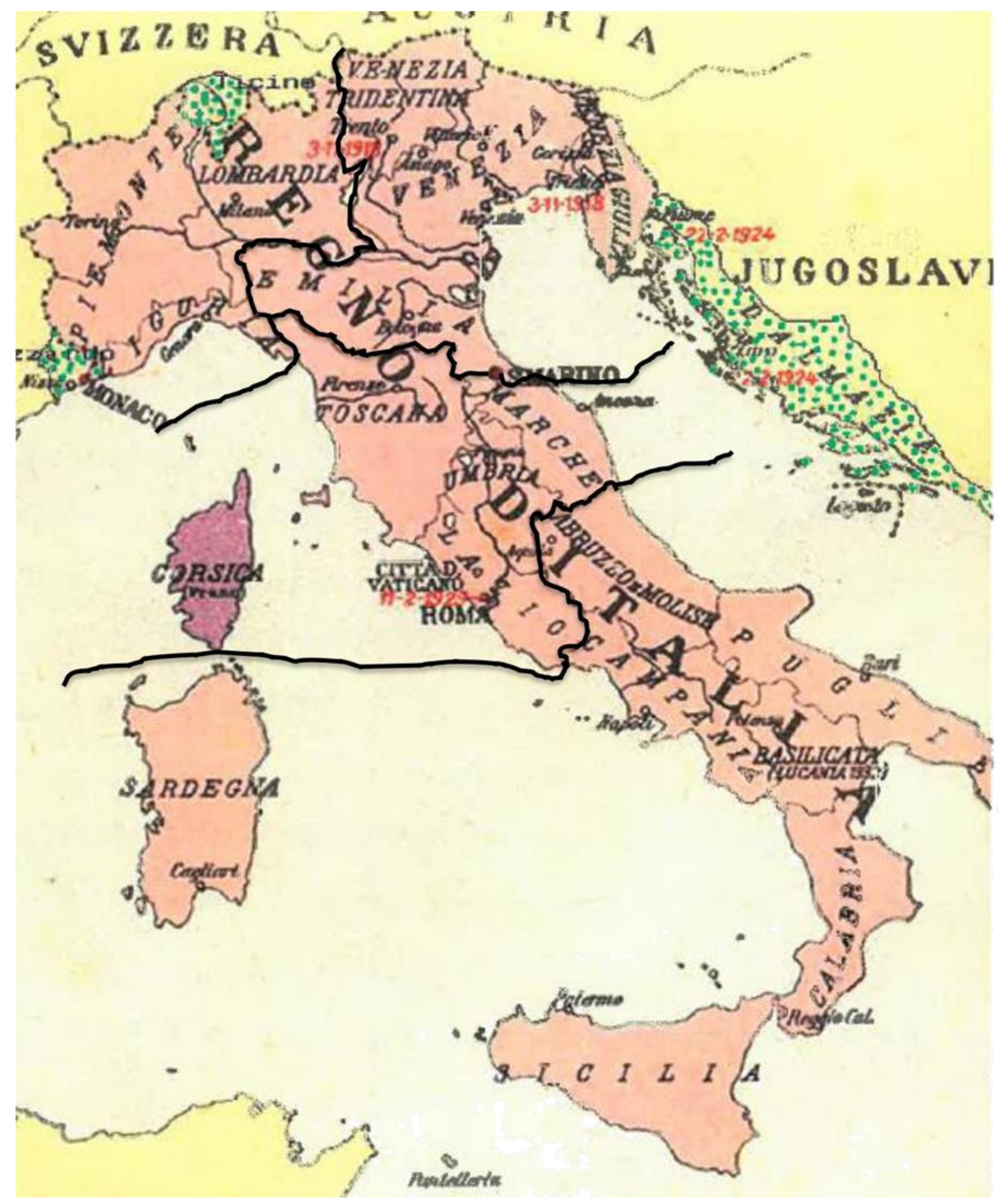

Macro-regions are: North-West (includes the regions Piemonte, Liguria, and Lombardia); North-East (includes the regions Venezia, Venezia Tridentina, Venezia Giulia, and Emilia-Romagna); Centre (includes the region Toscana, Lazio, Umbria and Marche); and South and Islands (includes regions Abruzzo e Molise, Campania, Puglie, Basilicata, Calabria, Sicilia and Sardegna). 
Three of the four major universal banks were headquartered in Milan, with only one, BdR, located in the capital city. As Tables 1 and 2 show, the geographical distribution of universal banks' and local banks' networks of interlocked businesses was concentrated to a great extent (40 percent and above) in the banks' own provinces throughout the period. Both groups of banks had broadened the geographical scope of their networks by the second benchmark year. However, while the expansion towards the national dimension continued until 1936 for the universal banks, this was not the case for the local banks that, instead, retrenched in their own macro-regions between 1927 and 1936.

The increase in national scope of the universal banks' network, observable in 1936, was led by BdR and Comit. The latter, in particular, was taken over by IRI in 1933 which led the bank severing its links with many firms in the North-West and creating new ties with both state-owned and private enterprises located in Rome where $I R I$ was headquartered. ${ }^{6}$ In fact, the government drastically downsized Comit's board of directors from 44 (1927) to 19 (1936) and appointed representatives of the new controlling shareholder, i.e. IRI. ${ }^{7}$ Also Credit's board of directors was downsized from 34 to 14 , but it retained some major private industrialists based in the North-West, including Giovanni Agnelli (owner and president of FIAT), Giacinto Motta (president of Edison, Italy's largest electricity company), and Lorenzo Bruzzo (a Genovese industrialist with concerns in the steel, shipping, chemicals, and sugarrefinery industries). By contrast, BdR's board was reduced only from 18 to 16 , but retained Antonio Pesenti, president of the nation's largest cement producer Italcementi.

Table 1. Major universal banks' networks by geographical distribution of interlocked firms (\%)

\begin{tabular}{|l|ccc|ccc|ccc|}
\hline & \multicolumn{3}{|c|}{1913} & \multicolumn{3}{c|}{1927} & \multicolumn{3}{c|}{1936} \\
HQ of interlocked firms & Min. & Median & Max. & Min. & Median & Max. & Min. & Median & Max. \\
\hline Same province & 41.7 & 43.5 & 77.3 & 19.7 & 41.8 & 46.2 & 34.3 & 40.2 & 40.3 \\
Same region & 44.0 & 50.1 & 77.3 & 19.7 & 45.3 & 52.8 & 34.3 & 41.1 & 43.1
\end{tabular}




\begin{tabular}{|l|lll|lll|lll|} 
Same macro-region & 66.7 & 69.8 & 77.3 & 30.3 & 63.2 & 75.4 & 39.4 & 51.9 & 77.5 \\
Other macro-region & 22.7 & 30.2 & 33.0 & 24.6 & 36.8 & 69.7 & 22.6 & 48.1 & 60.6 \\
\hline
\end{tabular}

Table 2. Top twenty local banks' networks by geographical distribution of interlocked firms (\%)

\begin{tabular}{|l|ccc|ccc|ccc|}
\hline & \multicolumn{3}{|c|}{1913} & \multicolumn{3}{c|}{1927} & \multicolumn{3}{c|}{1936} \\
HQ of interlocked firms & Min. & Median & Max. & Min. & Median & Max. & Min. & Median & Max. \\
\hline Same province & 8.3 & 42.3 & 100 & 4.7 & 40 & 84 & 3.9 & 45.4 & 92.9 \\
Same region & 25 & 76.2 & 100 & 9.7 & 69.2 & 92 & 8.3 & 83.9 & 100 \\
Same macro-region & 25 & 84.2 & 100 & 9.6 & 77.9 & 94 & 8.3 & 87.2 & 100 \\
Other macro-region & 0 & 15.8 & 75 & 6 & 22.1 & 90.3 & 0 & 12.8 & 91.7 \\
\hline
\end{tabular}

Table 2 shows the geographical distribution of the networks of the top twenty local banks. The differences amongst these networks were huge as indicated by the immense gap between their minimum and maximum values. In fact Lombard banks in particular had a high propensity to generate interlocks on the local level, whereas banks headquartered outside the North-West tended to create links not only with their local firms but also with firms located in other macro-regions, in particular the most industrialised macro-region the North-West.

The median value of affiliated firms located in other macro-regions rose from 16 to 22 percent between 1913 and 1927 to plummet to 12.8 percent in the last benchmark year. The geographical expansion of many local banks' networks occurred in the context of the unprecedented wildcat boom of the banking industry in the early 1920s, a time when Italian banks were subject to the Commercial Code of 1882 that did not distinguish between banking and other business activities - and was fostered by the expansionary monetary policy of the post-World War I years. As a result, between 1919 and 1926 the number of banks increased by 30 percent and that of bank branches nearly doubled (Toniolo, 1995).

However, the Great Depression caused many local banks' networks to lose most of their national scope and to retrench to the local and regional level, hence the sharp decrease of the median value in 1936 . The change was also prompted by the reform of the banking sector 
of 1931-1938, generally known as the 1936 Banking Reform Law, which gave the Bank of Italy increased regulatory powers over the banking sector (Battilossi et al., 2013). The three universal banks rescued by IRI, i.e. Credit, Comit, and BdR, were entitled to operate throughout the country. The banks included in our group of the 'Top 20 local banks' belonged to the institutional group of 'ordinary credit banks' and 'cooperative banks'. These types of banks could operate only at a regional or provincial level. ${ }^{8}$ Therefore, on the one hand the reshaping of the banking structure regulated competition and established clearer geographical boundaries between banks, thus ensuring supply of credit to regional economies (Carnevali, 2005); on the other hand, it reduced local banks' scope for generating networks beyond the local level.

The sectoral distribution of banks' interlocks is a debated topic in the literature on Italian industrialisation. Table 3 examines such distribution for the two groups of banks in each benchmark year. More detailed information on the sectoral distribution of the networks is included in the on-line statistical appendix. ${ }^{9}$ 


\section{Table 3. Sectoral distribution of interlocked firms}

\begin{tabular}{|c|c|c|c|c|c|c|c|c|c|c|c|c|c|c|c|c|c|c|}
\hline \multirow[b]{3}{*}{ Sector } & \multicolumn{6}{|c|}{1913} & \multicolumn{6}{|c|}{1927} & \multicolumn{6}{|c|}{1936} \\
\hline & \multicolumn{3}{|c|}{ Major Univ. Banks } & \multicolumn{3}{|c|}{ Top 20 Local Banks } & \multicolumn{3}{|c|}{ Major Univ. Banks } & \multicolumn{3}{|c|}{ Top 20 Local Banks } & \multicolumn{3}{|c|}{ Major Univ. Banks } & \multicolumn{3}{|c|}{ Top 20 Local Banks } \\
\hline & $\begin{array}{l}\% \\
\text { Firms }\end{array}$ & \begin{tabular}{|l|l|}
$\%$ \\
Assets
\end{tabular} & $\begin{array}{l}\text { Mean } \\
\text { assets* }\end{array}$ & $\begin{array}{l}\% \\
\text { Firms }\end{array}$ & $\begin{array}{l}\% \\
\text { Assets }\end{array}$ & $\begin{array}{l}\text { Mean } \\
\text { assets* }\end{array}$ & $\begin{array}{l}\% \\
\text { Firms }\end{array}$ & \begin{tabular}{|l|}
$\%$ \\
Assets
\end{tabular} & $\begin{array}{l}\text { Mean } \\
\text { assets* }\end{array}$ & $\begin{array}{l}\% \\
\text { Firms }\end{array}$ & $\begin{array}{l}\% \\
\text { Assets } \\
\end{array}$ & $\begin{array}{l}\text { Mean } \\
\text { assets* }\end{array}$ & \begin{tabular}{|l|}
$\%$ \\
Firms
\end{tabular} & \begin{tabular}{|l|l|}
$\%$ \\
Assets
\end{tabular} & \begin{tabular}{|l|} 
Mean \\
assets*
\end{tabular} & \begin{tabular}{|l|}
$\%$ \\
Firms \\
\end{tabular} & $\begin{array}{l}\% \\
\text { Assets }\end{array}$ & \begin{tabular}{|l|} 
Mean \\
assets*
\end{tabular} \\
\hline $\begin{array}{l}\text { Agriculture, forestry and } \\
\text { fishing }\end{array}$ & 2.2 & 1.8 & 13.0 & 1.3 & 2.1 & 15.9 & 2.7 & 1.1 & 32.6 & 5.2 & 2.3 & 24.1 & 1.9 & 1.0 & 104.3 & 4.0 & 1.4 & 33.5 \\
\hline Mining and quarrying & 3.9 & 1.7 & 6.6 & 1.7 & 0.5 & 2.7 & 4.4 & 1.9 & 34.0 & 3.1 & 0.8 & 14.2 & 3.1 & 0.4 & 23.1 & 1.7 & 0.4 & 25.0 \\
\hline Manufacturing & 47.0 & 36.7 & 12.2 & 62.0 & 51.9 & 8.2 & 42.4 & 34.0 & 63.8 & 45.9 & 31.5 & 38.0 & 37.6 & 17.9 & 93.8 & 50.5 & 24.1 & 44.9 \\
\hline - Light industry & 21.1 & 12.4 & 9.2 & 33.8 & 24.6 & 7.1 & 19.2 & 8.4 & 34.6 & 27.4 & 11.8 & 23.8 & 9.7 & 2.0 & 40.9 & 30.7 & 7.5 & 23.1 \\
\hline - Heavy industry & 25.9 & 24.3 & 14.6 & 28.3 & 27.3 & 9.4 & 23.2 & 25.6 & 87.9 & 18.4 & 19.7 & 59.1 & 27.9 & 15.9 & 112.1 & 19.8 & 16.5 & 78.7 \\
\hline $\begin{array}{l}\text { Electricity, gas and water } \\
\text { supply }\end{array}$ & 14.0 & 19.0 & 21.1 & 8.0 & 12.4 & 15.1 & 18.1 & 28.8 & 126.4 & 9.9 & 26.0 & 145.3 & 16.3 & 29.5 & 356.9 & 15.4 & 41.1 & 250.9 \\
\hline Construction & 3.5 & 2.9 & 12.7 & 3.0 & 1.9 & 6.3 & 2.9 & 0.8 & 22.9 & 3.1 & 0.9 & 16.3 & 4.3 & 1.5 & 69.2 & 2.1 & 1.6 & 71.6 \\
\hline Trade & 6.6 & 1.2 & 2.9 & 5.9 & 2.6 & 4.3 & 5.7 & 3.2 & 44.9 & 9.4 & 3.4 & 19.9 & 6.6 & 0.8 & 24.3 & 7.5 & 1.2 & 14.8 \\
\hline Transport and storage & 15.4 & 23.0 & 23.3 & 10.5 & 9.2 & 8.5 & 11.0 & 9.8 & 71.3 & 9.3 & 10.0 & 59.5 & 8.1 & 2.8 & 68.7 & 5.8 & 4.1 & 66.4 \\
\hline Telecommunications & & & & 0.8 & 0.2 & 1.8 & 0.8 & 1.7 & 174.3 & 1.0 & 2.7 & 143.8 & 1.6 & 4.1 & 516.2 & 0.6 & 0.7 & 109.4 \\
\hline Financials & 5.3 & 13.4 & 39.5 & 3.4 & 18.5 & 53.6 & 10.0 & 18.0 & 143.8 & 10.3 & 21.6 & 115.3 & 19.0 & 41.7 & 431.7 & 10.2 & 25.2 & 232.8 \\
\hline $\begin{array}{l}\text { Public administration, } \\
\text { health and social service }\end{array}$ & 1.8 & 0.4 & 3.6 & 3.4 & 1.0 & 2.8 & 2.1 & 0.5 & 20.2 & 2.5 & 0.7 & 15.0 & 1.6 & 0.2 & 31.4 & 1.7 & 0.2 & 8.7 \\
\hline Total & 100.0 & 100.0 & 15.6 & 100.0 & 100.0 & 9.8 & 100.0 & 100.0 & 79.5 & 100.0 & 100.0 & 55.3 & 100.0 & 100.0 & 196.7 & 100.0 & 100.0 & 94.3 \\
\hline
\end{tabular}

Key: *=Million Lire 
Similarly to Fohlin's (2007) findings for Germany, local banks were connected to nearly every sector of the corporate economy. However, Italian local banks had a higher proportion of affiliated firms in manufacturing. Thus, in 1913, manufacturing accounted for 62.0 percent of firms interlocked to the top twenty local banks, compared with 47.0 percent of firms affiliated to the major universal banks. Due to their smaller average size, the proportion of manufacturing firms on total assets of network membership is lower, but the bias in favour of local banks remains substantial (51.9 percent versus 36.7 percent).

In addition to manufacturing, two sectors stood out in the major universal banks' networks: electricity, gas and water supply; transport and storage (these banks were interlocked to Italy's largest railway and passenger shipping companies).

In 1927 we find a convergence in the sectoral distribution of affiliated firms between the major universal banks and the top twenty local banks. Heavy industry and electricalcommercial companies were now only slightly more represented among the former and light industry among the latter.

In 1936 we observe a new divergence between networks. Major universal banks' networks now differ remarkably one from another with Comit's network concentrated to an unprecedented proportion on finance companies, Credit focused more on large electrical commercial firms, and BdR in between. ${ }^{10}$ By contrast, local banks' networks hinged principally on manufacturing and electricity companies. In particular, the latter had jumped to 15.4 percent of firms and 41.1 percent of total assets, highlighting a change in the investment pattern of local banks towards less risky activities as local utilities.

An interesting feature is the presence of financials - both insurance and finance companies - in the networks of larger universal banks as well as some local banks. This raises the issue of the extent to which the large universal banks and the local banks were 
interlocked. A more detailed analysis highlights that in 1913 only two of the four major universal banks had interlocks with other banks: SBI with four, and BdR with one. Out of the twenty local banks, four were linked to major universal banks, of which two were linked also to Banca d'Italia, Italy's largest bank of issue. The situation changed in 1927, when all the major universal banks had developed a dense web of banking interlocks mainly with local banks. Conversely, the propensity of local banks to be networked to other banks also reached its apex in that benchmark year, with seventeen of them being linked to at least another bank, eight of which were networked to a universal bank. The number of bank connections fell dramatically in 1936 particularly for the universal banks. These dropped to three for Comit, two for BdR, and one for Credit. Also the twenty local banks' connections with the universal banks declined significantly, whereas their links with other local banks and central institutes of local banks increased.

These links between universal and local banks probably existed for the larger banks to have access to the funds collected in peripheral areas by the smaller banks. However, the majority of the top twenty local banks were disconnected from the large national banks: three had no banking interlocks and eight were connected only to other local banks. We can argue, therefore, that the extent to which local banks were linked to major universal banks - and therefore might function as branches of the latter - varied over time but was never the preponderant trait of local banking in Italy.

We can observe from Table 3 that size appears as a major difference between firms attached to the larger universal banks and firms attached to local banks. In all benchmark years we find the firms linked to the former were significantly larger than those linked to the latter. The bias of the larger universal banks' relationship towards largest firms was present with some exceptions - in all sectors. 
A focus on telecommunications can shed some light on the propensity of the various types of banks to establish ties with firms in well-established industries or instead with small firms in new fast-growing industries. In 1913 no large universal bank was connected to any telecommunication firms, whereas two small telecommunication firms were linked to as many local banks, even if the former accounted for a very low share of the total assets of the latter's affiliated firms. In 1927 the share of telecommunications is still higher in the networks of local banks, but the situation reversed in 1936. Thus, the impression is that small firms operating in the infant stage of their industries tended more often to be connected to small local banks but once they grew in size and became well-established companies, they moved to the networks of the larger universal banks that could more properly satisfy their increased financial needs.

The sectoral analysis above highlights that large universal banks were mainly connected with established industries whereas emerging industries, characterised by smaller average size were mainly connected with local banks. To further investigate we compared the age of businesses in the two networks and their level of risk, measuring the variability of profits, which is one of the standard indicators of risks (Brealey \& Myers, 2003).

Table 4. Profitability and age of interlocked firms

\begin{tabular}{|c|c|c|c|c|c|c|c|c|}
\hline & $\begin{array}{c}\text { Major } \\
\text { Universal } \\
\text { Banks }\end{array}$ & & & & $\begin{array}{l}\text { Top twenty } \\
\text { local banks }\end{array}$ & & & \\
\hline & $\begin{array}{l}\text { Profit / losses } \\
\text { (mean, } 000 \\
\text { lire) }\end{array}$ & C.V. & $\begin{array}{c}\text { Age } \\
\text { (Mean) }\end{array}$ & Obs & $\begin{array}{c}\text { Profit / losses } \\
\text { (mean, } 000 \\
\text { lire) }\end{array}$ & C.V. & $\begin{array}{c}\text { Age } \\
\text { (Mean) }\end{array}$ & Obs \\
\hline 1913 & 0.6 & 2.4 & 15.8 & 269 & 0.6 & $5.20 * * *$ & $12.7 * * *$ & 310 \\
\hline
\end{tabular}




\begin{tabular}{|c|c|c|c|c|c|c|c|c|}
\hline 1927 & 3.5 & 3.7 & 16.7 & 810 & & & & \\
\hline 1936 & 5.3 & 2.6 & 22.1 & 295 & $3.5^{* * *}$ & $4.74 * * *$ & $14.8^{* * *}$ & 852 \\
\hline
\end{tabular}

Notes: we have used coefficients of variation (C.V.), rather than standard deviations, as the coefficient of variation seems more appropriate to compare different samples;

We tested whether the differences between the two groups of interlocked firms are statistically significant: $* * *$ $\mathrm{p}<0.01, * * \mathrm{p}<0.05, * \mathrm{p}<0.1$.

Table 4 shows that overall the top twenty local banks were interlocked to younger, riskier, and less profitable firms. The coefficient of variation (C.V.), indicator of risk, is consistently higher than the counterpart figures for the major universal banks and the differences are highly statistically significant. An exception is the mean profit in the first benchmark year, for which the values are very close and their difference is not statistically significant.

Overall, Table 4 confirms that a more geographically concentrated network of the local banks also meant that less profitable and riskier industrial concerns could benefit from external finance and business advice. This is consistent with the approach by Stiglitz \& Weiss (1990) who emphasized that screening and assessing the credit worthiness of loan applicants is one important function performed by banks, which will endeavour to select low-risk borrowers and will follow up by monitoring them. These are costly functions due to the opacity of the credit market and information asymmetries. However, the embeddedness of banks and borrowers in the same economic and social fabric lowers information asymmetries through less costly direct and informal knowledge, which in turn enables an assessment of the credit worthiness of borrowers based not merely on financial criteria, thus enabling SMEs perceived as riskier on the basis of their accounts to access credit (Carnevali, 1996; Conti \& 
Ferri, 1997). Therefore, the top twenty local banks performed an important role in interlocking with businesses that other financial institutions may not have considered creditworthy and that were nevertheless important for the Italian economy.

The major universal banks demonstrate a cautious stance by interlocking with less risky concerns than those of the top twenty local banks. A more risk-prone approach is suggested by the 1927 figures, which might be explained by a wave of new industrial concerns being established in the fast growth years between 1922 and 1925, which ended with a sharp fall in the stock market (Toniolo, 1995). The level of risk decreased, and the age increased considerably, in the last benchmark year, suggesting a widespread risk aversion following the Great Depression and the subsequent salvaging of banks and industrial concerns by the state. Both the Great Depression and state intervention reshaped the industrial structure of the country and the state-controlled system of industrial credit reduced the instability in both the industrial and banking systems.

\section{Directionality of interlocks}

An analysis of the directionality of interlocks provides some further insights about the nature of the relationship between banks and industry. This assumes that the direction of the interlock goes from the company in which a director holds a more important position to that in which his position is of a lesser importance. As a result, the interlock becomes an instrument for the former company to exert an influence on the latter (Pennings, 1980; Wasserman \& Faust, 1994). We have defined the following hierarchy of the importance of board positions in Italian joint-stock companies to identify the directionality of interlocks: 
President $=\mathrm{CEO} \rightarrow$ Executive Manager $\rightarrow$ Vice-President $\rightarrow$ Secretary of the Board $\rightarrow$ Director

According to this methodology, in the case of the links between banks and industry, two types of directed interlocks can be detected: those that go from the bank to the industrial firm and those that go in the opposite direction. We refer to the former as to the outdegree, which is an indicator for the influence banks had on industry; and vice versa to the latter as to the indegree that expresses the influence of industry on banks. ${ }^{11}$ Thus, following Windolf (2009, 2010), we have computed the outdegree/indegree ratio: the higher this indicator, the more dominant banks are over industry, and vice versa.

Table 5 shows that in all benchmark years, directed interlocks account for a higher proportion of total interlocks with industrial firms ${ }^{12}$ for the major universal banks than is the case for the top twenty local banks. For the former, the proportion of directed interlocks increased between 1913 and 1927 but then it slightly decreased in 1936, whereas for the latter the Great Depression seems to have had an opposite effect and the proportion of directed interlocks rose to its highest value in 1936.

As we move on to the direction of interlocks, we observe that throughout the period investigated both large universal banks and small local banks had in the average more indegrees than outdegrees. ${ }^{13}$ Thus, the ratio outdegree/indegree is always $<1$. In 1913 and 1927 this ratio is higher - even if slightly - for universal banks, but in 1936, after these had been taken over by IRI, it drops to its lowest value (0.3) and now the ratio is higher for the top twenty local banks for which it remains stable at the same level as in $1927(0.8)$. Thus, the Great Depression and the 1930s restructuring of the banking system seem to have affected the 
relationship with industry much more for the major universal banks than it was the case for local banks.

As we have anticipated, this ratio can be interpreted as an indicator for bank hegemony. In our case, as this ratio is always $<1$, but with values often not much lower than 1 , we can infer that the relationship between banks and industry in Italy was fundamentally one of mutual dependency, with a slightly higher influence of industry over banks, a situation which makes Italy more in line to the 'resource dependence' model than to the 'bank control' model.

The high proportion of indegrees in the structure of Italian banks' interlocks posed a problem. In fact, such a circumstance increased the risk of bankruptcy among banks because of the influence the actual or potential debtors were able to exert on the creditor banks. And this was probably one of the causes of the high instability of the Italian banking system until the 1930s.

Table 5: Directionality of interlocks

\begin{tabular}{|l|c|c|c|c|c|c|}
\hline \multirow{2}{*}{} & \multicolumn{2}{l}{ Large universal banks } & \multicolumn{2}{l}{ Top twenty local banks } \\
\cline { 2 - 6 } & 1913 & 1927 & 1936 & 1913 & 1927 & 1936 \\
\hline Total number of interlocks with industrial firms (1) & 343 & 1,041 & 276 & 349 & 1,025 & 709 \\
\hline Directed interlocks with industrial firms [\% of (1)] & 54.8 & 59.8 & 59.4 & 46.4 & 52.0 & 55.3 \\
\hline Number of outdegrees (2) & 85 & 295 & 37 & 63 & 231 & 129 \\
\hline Outdegrees per bank & & & & & & 6.4 \\
\hline Number of indegrees (3) & 21.2 & 73.8 & 12.3 & 3.2 & 11.6 & 6.4 \\
\hline Indegrees per bank & 103 & 327 & 127 & 99 & 302 & 162 \\
\hline Outdegree / Indegree ratio [(2) / (3)] & 25.8 & 81.8 & 42.3 & 5.0 & 15.1 & 8.1 \\
\hline Total number of industrial firms interlocked (4) & 225 & 627 & 233 & 237 & 670 & 513 \\
\hline Industrials firms receiving banks' outdegrees [\% of (4)] & 32.4 & 32.9 & 15.0 & 20.7 & 27.8 & 23.6 \\
\hline
\end{tabular}


Figure 2 shows that, in comparative perspective, the outdegree/indegree ratio of Italian banks was significantly lower than that in other countries. Even though the samples of the various countries reported in Figure 2 were selected using different methodologies, and therefore are not exactly comparable, the differences in the orders of magnitude are striking. ${ }^{14}$ The outdegree/indegree ratio was particularly high in Germany, where banks had a more dominant position in the corporate system, but was also significantly higher in the USA. Instead, in France the ratio was much more similar to Italy's and this indicates a more reciprocal relationship between banks and industry within these two countries.

\section{Figure 2: Outdegree/Indegree ratio in some selected countries}

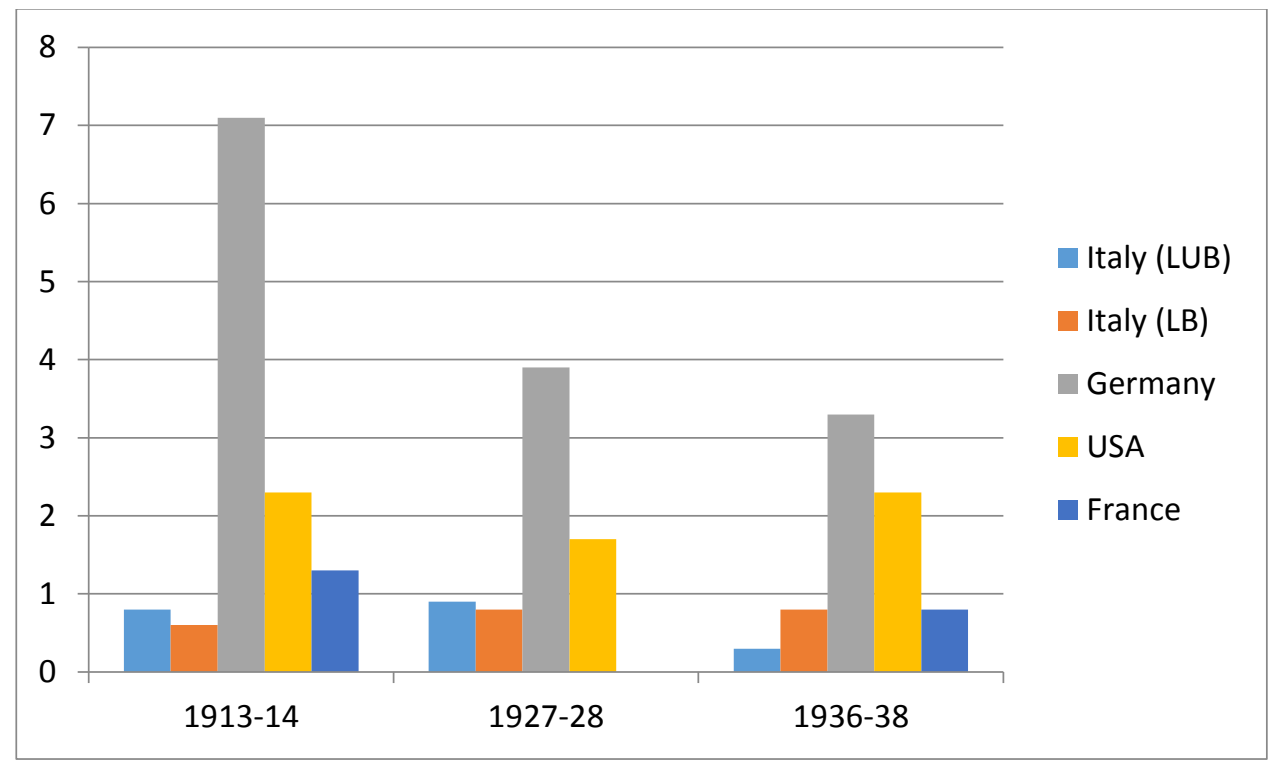

Keys: LUB = Large universal banks; LB = Top 20 local banks.

Source: For Germany, USA and France: Windolf (2009, 2010); for Italy: Imita.db

In examining bank influence over industry, we must also investigate the proportion of industrial firms that received outdegrees from banks. The last row in Table 5 shows that the figure for industrial firms linked to large universal banks is about one third in 1913 and 1927, 
but then it dramatically drops to 15 percent in 1936. Conversely, the corresponding figure for the top twenty local banks is lower in the first two benchmark years, but then in 1936 the situation reverses and in that year local banks sent outdegrees to a higher proportion of industrial firms (23.6 percent) to which they interlocked than it was the case for larger universal banks.

Nonetheless, as it is shown in Figure 3, this indicator is also much lower than for Germany and the USA, to further underscore the higher influence of banks over industry in these two countries. Once again, the figures of Italy are much more in line with those of France, which had a more similar proportion of industrial firms receiving outdegrees from banks.

Figure 3: Industrial firms receiving banks' outdegrees (\%)

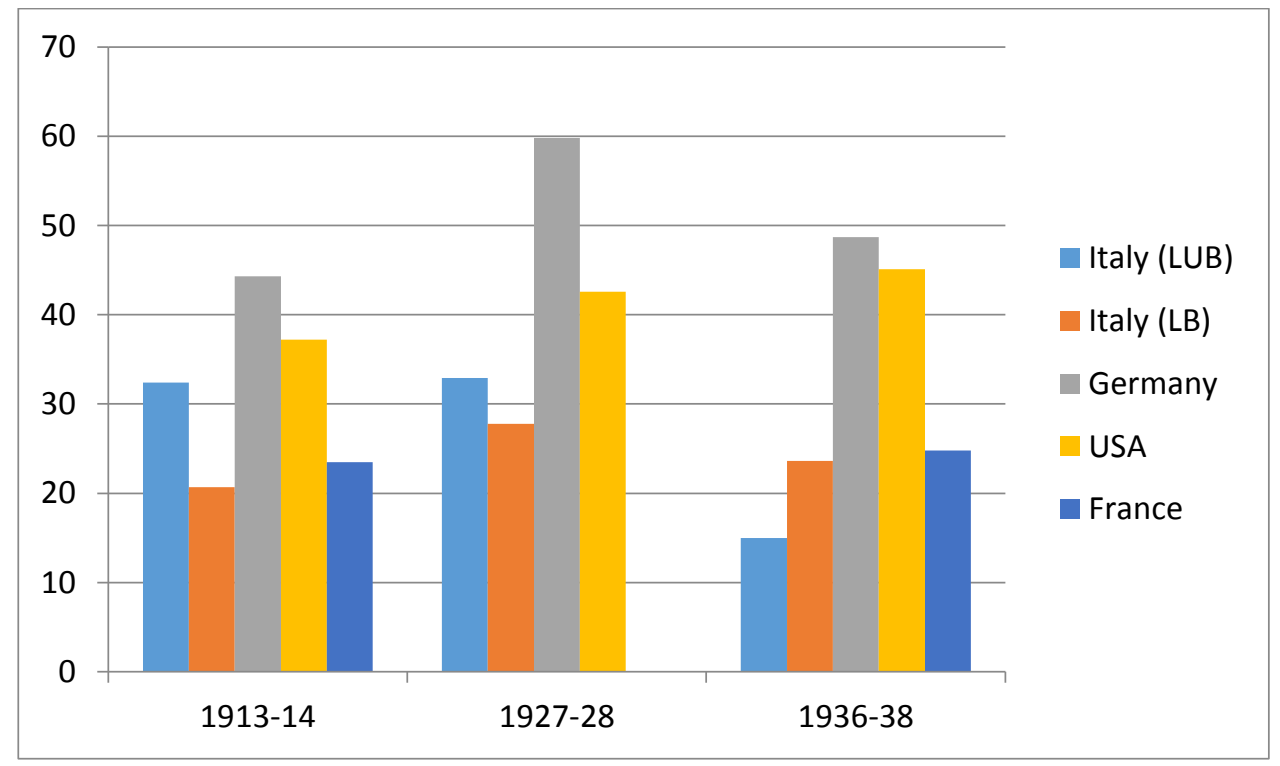

Keys: LUB = Large universal banks; LB = Top 20 local banks.

Source: For Germany, USA and France: Windolf (2009, 2010); for Italy: Imita.db 
Thus, our overall picture on the directionality of interlocks provides no evidence in favour of the 'bank-control' model. It is rather in line with the 'resource dependence' model. This insight is further corroborated by the high proportion of undirected interlocks between banks and industry. Thus, interlocking directorates seem to be driven principally by a convergence of interests between banks (monitoring customers) and industrial firms (interested in tapping capital and credit flows), with the latter exerting a slightly higher influence over the former.

\section{Case studies}

The two case studies below provide insights into the networks of interlocking directorates of local banks. From the four local banks ranked among the 'Top 20 local banks' in all the three benchmark years, i.e. the Banca Lombarda di Depositi e Conti Correnti, Banco Lariano, Banca di Legnano, and Credito Commerciale all located in the region of Lombardy, we selected two banks for which some literature is available in addition to the reports on inspections conducted by the Banca d'Italia between 1926 and 1936.

The Banca Lombarda di Depositi e Conti Correnti (henceforth Banca Lombarda) was established in Milan in 1870 with a share capital of 6 million lire and was the first joint-stock bank in the region of Lombardy (Cafaro, 2000). In 1913 it was interlocked to 33 firms, which rose to 53 in 1927. By 1932 it had reached a share capital of 24 million and had established various branches in the region. ${ }^{15}$ The Banca Lombarda's directors were representatives of the local industrial elite. At the time of the Banca d'Italia's 1932 inspection report, the Banca Lombarda's president, Luigi Bellini, was also president of the Banca per il Commercio Serico 
(Bank for the Commerce of Silk) and president of a firm specialised in the ageing of silk (Società Anonima Stagionatura Seta). The Banca Lombarda's vice-president, Andrea Pedroni, was also the owner of an industrial concern in the silk industry. Banca Lombarda's board of directors was mainly made of industrialists in the silk and textile industries, and to a lesser extent in the steel and electricity industries, in addition to bankers and aristocrats some of whom were also involved in industry and banking. For instance, one of the directors, Mauriziano Piantanida, was also the manager of the Banca d'Italia's branch in Milan; Darvino Salmoiraghi was also a director at the Credito Commerciale in Cremona (Lombardy); and Polidoro Redaelli was also a syndic at the Credito Commerciale di Verona (Veneto) and had previously been managing director at the Banca Popolare in Milan. In 1936 the Banca Lombarda was interlocked to 36 firms.

The Banca d'Italia's scrutiny of the loans and commercial papers extended by the Banca Lombarda indicates its great involvement in a range of industries, including steel (Società Anonima Acciaierie e Ferriere Lombarde Falk), electricity and telephones (E.L.T.E Società Elettro Telefonica), automobile industry (Alfa Romeo and Società Anonima Italiana Pirelli), and mechanical engineering (Società Anonima E. Marelli \& C. Magneti), in addition to textiles and silk. The report identified some bad loans and some excessive loans considering the financial situation of the borrowers, nevertheless the report states that the financial situation of the Banca Lombarda was solid. Furthermore, the report identifies some irregularities and infringements of rules in extending loans and poor book-keeping, and interpreted these as a result of the relationship between the bank and its clientele based on personal knowledge and trust, as well as the bank's paternalistic approach to extending credit in the local economy. ${ }^{16}$ 
The Banca di Legnano (henceforth BdL) was established in 1887 with the aim of collecting the abundant local savings and making them available to industrial and commercial enterprises operating in the area, essentially the Northern part of the Milan province. In 1913, BdL had interlocks with 19 firms, which jumped to 74 in 1927 but then halved to 37 in 1936 . By 1932, BdL was particularly involved with textile and mechanical engineering enterprises and, with its seven branches, was considered one of the major credit institutions in the area. ${ }^{17}$ The local involvement dominated the operations of the BdL in the first decade of its life. Following the economic crisis of the early 1890s and the demise of the Italian Crédit Mobilier, large local industrialists became interested in their 'local bank' as opposed to large banks, the management of which was more difficult to influence. Furthermore, the management of the ambitious CEO Angelo Pogliani directed the BdL towards high-finance operations (Cafaro, 2000; De Luca, 2005). Some prominent local industrialists were members of BdL's board of directors, thus for instance Baron Eugenio Cantoni was its first president and Eugenio Tosi chaired the board from 1913 until 1930. These gentlemen were also the owners and presidents of two among the largest firms in the area, the Cantoni (textiles) and Franco Tosi \& Co. (mechanical engineering), which employed 3,000 and 1,500 workers respectively. ${ }^{18}$ Eugenio Cantoni was a strong supporter of the presence of industrialists in banking institutions and had been on the board of other banks in Northern Italy (Cafaro, 2000). Moreover, the textile industrialist Carlo Dell'Acqua was a director both in the BdL and Credito Varesino.

Banca d'Italia's 1932 inspection report mentioned the involvement of local industrialists as a factor contributing to the solid financial position of BdL as they provided an insiders' knowledge of the credit worthiness of borrowers. ${ }^{19}$ Furthermore, BdL's embeddedness in the local economy meant that financial transactions were supported by 
personal relationships and trust. In some cases, this allowed small concerns to overcome the hurdle of lack of collaterals (De Luca, 2005). Figure 4 below shows the dense network of interlocks developed by the BdL by 1927 . Some enterprises that played a significant role in Italian history can be recognised in the network, such as the engineering enterprise Ansaldo and the department-store chain la Rinascente.

Figure 4: The Banca di Legnano network of interlocking directorates, 1927

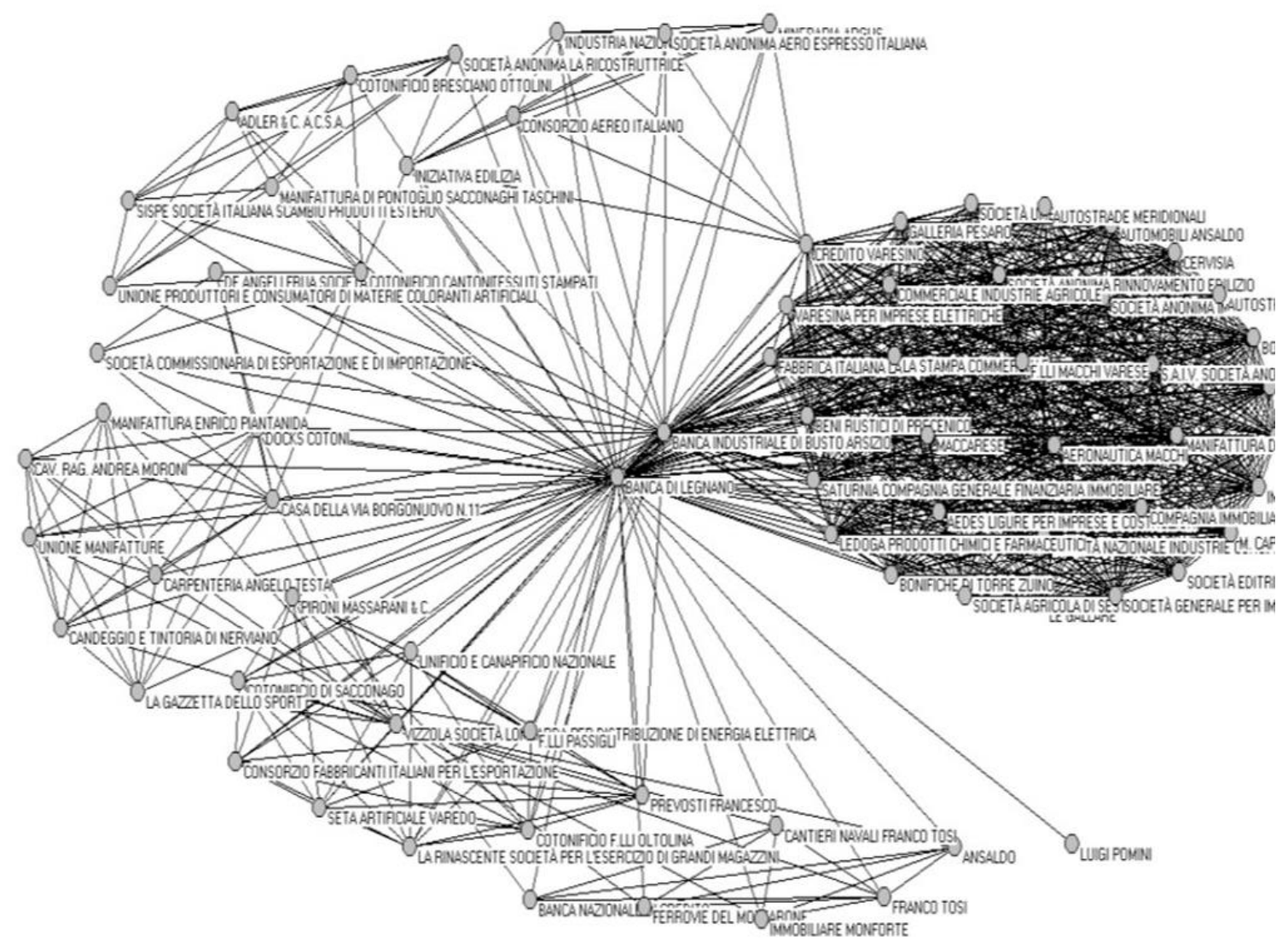

The presence of large enterprises among BdL's customers meant that it had to resort to interbank lending to meet the financial requirements of its clientele and the second largest universal bank (Credit) was a major source of interbank lending (Piluso, 2009). Credit also 
supported BdL in 1915, when it was badly affected by the bankruptcy of a bicycle manufacturer that had considerable debts with the bank. In 1921, Credit bought shares in the BdL for 4.5 million lire, a large fraction of BdL's share capital which amounted to 20 million lire in $1932 .^{20}$

\section{Conclusions}

This article examined some important and previously unexplored facets of the bankingindustry relationships in a critical period of Italian industrialisation. We investigated the differences between the interlock networks of the major universal banks and a sample of local banks, before moving on to the central question, never investigated in the Italian case, of the directionality of the relationship.

Important differences between the two networks emerged. The bias of the major universal banks' relationship with largest firms could be detected throughout the three benchmark years and - with some exceptions - in all sectors. Firms in manufacturing, especially in light industry, had a greater weight in the networks of local banks, whereas industries such as electricity, transport and storage, and financials were more represented in the networks of universal banks. Local banks' networks were more structured on the local level, with a higher proportion of interlocked firms located in the same province and region as the bank. Lastly, we found that local banks were interlocked to riskier and less profitable firms. This confirms that more geographically concentrated networks of local banks also meant that less profitable and riskier industrial concerns could benefit from external finance and business advice. Thus, local banks performed an important role in interlocking with businesses that other financial institutions may have not considered credit-worthy but were 
nevertheless important for the Italian economy. This supports the argument by Stiglitz and Weiss conferring local banks an advantage in screening and monitoring small businesses.

A central question in our analysis is whether the industry-banking relationship in Italy reflected the hegemony of banks and followed a 'bank-control' model. The insights provided by our quantitative analysis and case-studies of local banks do not support that view. They rather indicate that, both in the case of universal banks and small local banks, interlocking directorates were driven principally by a convergence of interests between banks (monitoring customers) and industrial firms (interested in tapping capital and credit flows), with the latter exerting a slightly higher influence over the former. This significantly differentiates Italy from Germany and the United States, where banks had a more dominant position in the corporate system.

We have also shown that the creation of interlocks with other banks was a common practice for local banks already before World War I. The extent to which they were linked to large national banks - and therefore might function as branches of the latter - varied over time but was never the preponderant trait of local banking in Italy, the majority of their interlocks being with other local banks. So, our evidence seems to confirm that local banks were largely part of a system of interlocks that existed independently of the one centred on the larger universal banks and that only in part redressed the segmentation of the Italian banking system.

Overall, our results challenge Gerschenkron's claim that Italian industrialisation was fundamentally prompted by two great banks, which were both financial intermediaries and the main industrial policy players of the nation. Our evidence suggests that, although his thesis was mainly related to the new capital-intensive sectors of the second industrial revolution, Gerschenkron seems to have underestimated the resource mobilisation occurring in the 
regional economies and the role played by local banks in financing small firms especially in light-industry sectors. Our evidence is instead some way in line with Fohlin's findings that downplay the role of universal banks as the latter tended to establish their networks on large well-established companies instead of trying to create connections with promising, but risky, small firms, which needed venture capital. 


\section{References}

Aldrich, H., \& Pfeffer, J. (1976). Environments of Organizations. In A. Inkeles, J. Coleman \& N. Smelser (Eds.). Annual Review of Sociology, 2, 79-105.

Battilossi, S., Gigliobianco, A., \& Marinelli, G. (2013). Resource Allocation by the Banking System. In G. Toniolo (Ed.). The Oxford Handbook of the Italian Economy since Unification. (pp. 485-515). Oxford, UK: Oxford University Press.

Brealey, R.A., and Myers, S.C. (2003). Principles of Corporate Finance. Boston, MA: McGraw-Hill/Irwin.

Cafaro P. (2000). Alle origini del sistema bancario in Lombardia: Casse di risparmio e banchieri privati. In G. Conti \& S. La Francesca (Eds.). Banche e Reti di Banche nell'Italia Postunitaria (pp. 437-502). Bologna, Italy: Il Mulino.

Carnevali, F. (1996). Between Markets and Networks: Regional Banks in Italy. Business History, 38 (3), 83-100.

Carnevali, F. (2005). Europe's Advantage: Banks and Small Firms in Britain, France, Germany, and Italy since 1918. Oxford, UK: Oxford University Press.

Cohen, J. (1967). Financing Industrialization in Italy, 1894-1914: The Partial Transformation of a Late-Comer. Journal of Economic History, 27 (3), 363-382.

Conti, G. (1999). Le banche e il finanziamento industriale. In F. Amatori, D. Bigazzi, R. Giannetti \& L. Segreto (Eds.). Storia d'Italia: Annali 15. L'industria (pp. 443-504). Turin, Italy: Einaudi. 
Conti, G., \& Ferri, G. (1997). Banche locali e sviluppo economico decentrato. In F. Barca (Ed.). Storia del capitalismo italiano dal dopoguerra a oggi (pp. 429-465). Rome, Italy: Donzelli.

David, T., \& Westerhuis, G. (Eds.). (2014). The Power of Corporate Networks. A Comparative and Historical Perspective. New York, NY: Routledge.

De Luca, G. (2005). La Costruzione della Fiducia. La Banca di Legnano, le Imprese e il Territorio tra Miracolo Economico e Globalizzazione. Legnano Italy: Banca di Legnano.

De Nooy, W., Mrvar, A., \& Batagelj, V. (2011). Explanatory Social Network Analysis with Pajek. New York, NY: Cambridge University Press.

Fohlin, C. (1998). Fiduciari and firm liquidity constraint: the Italian experience with German-style universal banking. Explorations in Economic History, 35 (1), 83-107.

Fohlin, C. (1999). Capital mobilisation and utilisation in latecomer economies: Germany and Italy compared, European Review of Economic History, 3 (2), 139-174.

Fohlin, C. (2007). Finance Capitalism and Germany's Rise to Industrial Power. Cambridge University Press, New York.

Gerschenkron, A. (1962). Economic Backwardness in Historical Perspective. Cambridge, MA: Cambridge University Press.

Kotz, D. (1978). Bank Control of Large Corporations in the United States. Berkeley, CA: University of California Press.

La Francesca, S. (2004). Storia del Sistema bancario italiano. Bologna, Italy: Il Mulino.

Lescure, M. (2008). Banking and Finance. In G. Jones \& J. Zeitlin (Eds.). The Oxford Handbook of Business History (pp. 319-346). Oxford, UK: Oxford University Press. 
Mintz, B., \& Schwartz, M. (1985). The Power Structure of American Business. Chicago, IL: University of Chicago Press.

Pennings, J.M. (1980). Interlocking Directorates: Origins and Consequences of Connections Among Organizations' Boards of Directors. San Francisco/London: Jossey-Bass.

Pfeffer, J. (1988). A Resource Dependence Perspective on Intercorporate Relations. In M. Mizruchi \& M. Schwartz (Eds.). Intercorporate Relations: The Structural Analysis of Business (pp. 25-55). Cambridge: Cambridge University Press.

Pfeffer, J., \& Salancik, G.R. (1978). The External Control of Organizations: A Resource Dependence Perspective. New York/London: Harper \& Row.

Piluso, G. (2009). Le banche locali in Italia: pluralità e segmentazione. In G. Conti, O. Feiertag \& R. Scatamacchia (Eds.). Credito e nazione in Francia e in Italia (XIX-XX secolo) (pp. 245-267). Pisa, Italy: Pisa University Press.

Rajan, R., \& Zingales, L. (2003). The Great Reversals: The Politics of Financial Development in the Twentieth Century. Journal of Financial Economics, 69 (1), 5-50.

Stiglitz, J.E., \& Weiss, A. (1981). Credit Rationing in Markets with Imperfect Information. The American Economic Review, 71 (3), 393-410

Stiglitz, J.E., \& Weiss, A. (1990). Banks as Social Accountants and Screening Devices for the Allocation of Credit [Supplemental material]. Greek Economic Review, 12, 85-118.

Stokman, F.S., Ziegler, R. \& Scott, J. (Eds.). (1985). Networks of Corporate Power. A Comparative Analysis of Ten Countries. Cambridge, UK: Polity.

Teti, R. (1999). Imprese, imprenditori e diritto. In F. Amatori, D. Bigazzi, R. Giannetti, \& L. Segreto (Eds), Storia d'Italia. Annali 15: L'industria (pp. 1211-1303). Turin, Italy: Einaudi. 
Toniolo, G. (1995). Italian Banking, 1919-1936. In C.H. Feinstein (Ed.). Banking, Currency, and Finance in Europe Between the Wars (pp. 296-314). Oxford, UK: Clarendon Press.

Useem, M. (1984). The Inner Circle. New York: Oxford University Press.

Vasta, M., \& Baccini, A. (1997). Bank and Industry and Italy 1911-1936: New Evidence Using Interlocking Directorates Technique. Financial History Review, 4 (2), 139-159.

Vasta, M. (2006). Appendix: The Source and the Imita.db Dataset. In R. Giannetti and M. Vasta (Eds.). Evolution of Italian Enterprises in the $20^{\text {th }}$ Century (pp. 269-273). Heidelberg, Germany: Physica Verlag. [The database is available online: http://imitadb.unisi.it]

Vasta, M., Drago, C., Ricciuti, R., \& Rinaldi, A. (2017). Reassessing the bank-industry relationship in Italy, 1913-1936: A counterfactual analysis. Cliometrica, 20 (2), 183-216.

Wasserman, S., and Faust, K. (Eds.). (1994), Social Network Analysis. Methods and Applications. Cambridge: Cambridge University Press.

Windolf, P. (2009). Coordination and Control in Corporate Networks: United States and Germany in Comparison, 1896-1938. European Sociological Review, 25(4), 443-457.

Windolf, P. (2010). Germany, France and the US: A Statistical Network Analysis (19001938). Paper presented at the International Workshop "Corporate Networks in Europe during the 20th Century", Utrecht, November 12-13.

\footnotetext{
${ }^{1}$ The database is available online: http://imitadb.unisi.it. For the details of Imita.db, see Vasta (2006).

${ }^{2}$ Bankruptcies and mergers changed over time the landscape of universal banks in Italy: BdR was founded in 1880, Comit in 1894, Credit in 1895, and SBI in 1904. SBI merged in 1914 with the Società Italiana di Credito Provinciale, establishing the Banca Italiana di Sconto which bankrupted in 1921. What remained of the latter gave rise to the BNC, which in 1930 merged with Credit.
} 
${ }^{3}$ We considered as local banks the totality of banks included in Imita.db except the major universal banks; the banks of issues (Banca d'Italia and, until 1926, Banco di Napoli and Banco di Sicilia); the "public law banks" according to the Banking Law of 1936 (Banca Nazionale del Lavoro, Monte dei Paschi di Siena, Istituto Bancario San Paolo di Torino, Banco di Napoli and Banco di Sicilia); and the central institutes of the cooperative banks and the savings banks.

${ }^{4}$ During the period investigated in this article, the 1882 Commercial Code regulated corporate governance in Italy. This had designed a two-board system of corporate administration in which the assembly of the shareholders appointed the two following boards: 1) the board of directors (Consiglio di amministrazione), which was the executive body of the assembly of the shareholders. This usually included both inside and outside directors; 2) the board of syndics (Collegio sindacale), which monitored the financial probity of the firm and whose function did not coincide with that of the supervisory board in the German system (Teti, 1999). Thus, similarly to what was done in the two major international research projects on corporate networks in comparative perspective (Stokman, Ziegler \& Scott, 1985; David \& Westerhuis, 2014), for our analysis we have selected only members of the board of directors.

${ }^{5}$ In network analysis, the degree of a node is the number of edges connected to it (De Nooy, Mrvar and Batagelj, 2011).

${ }^{6}$ The cut of ID links, however, did not necessarily imply a shift in the geographical specialization of Comit's credit relationships.

${ }^{7}$ Among the state-owned enterprises located in Rome and now interlocked with Comit, stood out ANIC (chemicals); Finmare (IRI's sub-holding in charge of the shipping industry); IMI (Italy's largest industrial credit institute); INA (Italy's monopolist in life insurance) and IRI itself. At the same time Comit became connected with several private enterprises headquartered in Rome, operating in real estate, construction, insurance, public transport and utilities.

${ }^{8}$ Only banks with deposits amounting to more than 300 billion lire could operate in the regions where their head offices were located. Banks with deposits below that threshold could operate in the whole province if their head office was located in the provincial capital otherwise in the municipalities where the head office and branches were located (Battilossi et al., 2013).

${ }^{9} \mathrm{We}$ decided to separate the banking sector because the assets of banks are usually much higher than those of firms in other industries. Thus, addressing the sectoral distribution of banks' interlocks by including simultaneously all sectors in the analysis would have blurred the differences between network membership in industries other than banking. We also excluded real estate because of the large number of missing data in this sector.

${ }^{10}$ Thus, in 1936 finance companies accounted for 41.5 percent of the assets of affiliated companies for Comit, 33.0 percent for BdR, and 17.9 percent for Credit. By contrast, the share of electrical commercial firms was 19.7 percent for Comit, 23.1 percent for BdR, and 36.2 percent for Credit.

${ }^{11}$ Our methodology differs from the one used by Windolf $(2009,2010)$ for Germany, France and the USA. For Germany, where there is a two-board system of corporate governance, he defines outdegrees of the banks the interlocks in which members of banks' executive boards were sent to industrial companies' supervisory boards and, vice versa indegrees the interlocks in which members of industrial companies' executive boards sat on banks' supervisory boards. For France and the USA, which similarly to Italy have a one-board system, he establishes that if an executive manager of firm A sits on the board of directors of firm B as a non-executive or an external director, this person creates a directed interlock. In the case of Italy, we think that our procedure can be preferred as it has the advantage to give a directionality to a higher number of interlocks and thereby it provides a more comprehensive picture of the ties between banks and industry.

${ }^{12} \mathrm{We}$ define industrial firms as all firms operating outside the financial sector.

${ }^{13}$ The most important exception was Comit - the largest universal bank - in 1913, whose outdegree/indegree ratio was 1.7. However, after World War One the ratio plummets below 1 also for this bank, its values being 0.9 in 1927 and 0.3 in 1926.

${ }^{14}$ Data on Germany, France and the USA are drawn from Windolf (2010). For each of these countries, the sample selection was based on published lists of the largest corporations in some benchmark years and its size varies over time. Thus, for Germany the sample consists of the top 346 companies (45 banks) in 1914; the top 377 companies (51 banks) in 1928, and the top 361 companies (40 banks) in 1938. For the USA: the top 242 companies ( 36 banks) in 1914; the top 369 companies (46 banks) in 1928; the top 409 companies (53 banks) in 1938. For France: the top 292 companies (32 banks) in 1914; and the top 274 companies (31 banks) in 1938.

15 Archivio Storico della Banca d'Italia (ASBI), Vigilanza sulle Aziende, Pratiche, n.1302.0, fascicolo1, Rapporto sull'ispezione eseguita dal capo ufficio f.f. Vladimiro Liguori alla Banca Lombarda di Depositi e Conti Correnti in Milano, 14 Giugno 1932. 


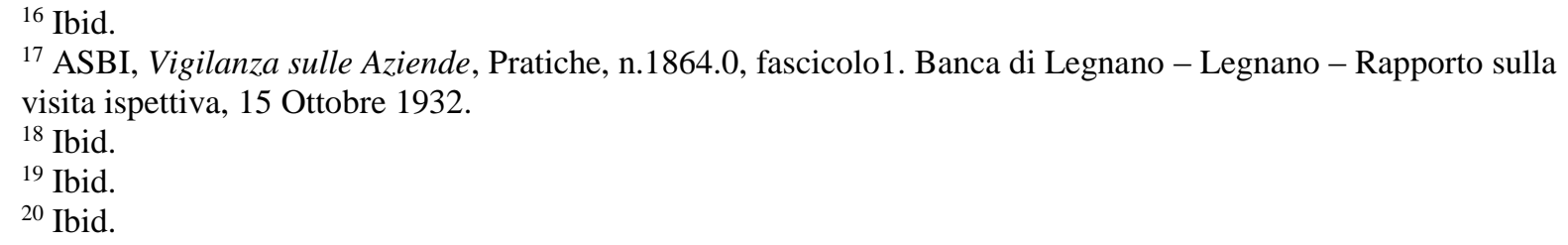

${ }^{19}$ Ibid.

${ }^{20}$ Ibid. 